\title{
Corporate social responsibility and environmental protection
}

\author{
Irina Verchagina $^{1^{*}}$, Irina Kolechkina $^{1}$, and Svetlana Grigashkina ${ }^{2}$ \\ ${ }^{1}$ T.F. Gorbachev Kuzbass State Technical University, Belovo Branch, 652644, Ilyica st. 32, Belovo, \\ Russian Federation \\ ${ }^{2}$ T.F. Gorbachev Kuzbass State Technical University, 28, Vesennyaya st., Kemerovo, 650000, Russian \\ Federation
}

\begin{abstract}
The article explores the issue of the place and significance of measures for environmental protection and environmental management in the system of social responsibility of business. The retrospective of the concept of social responsibility of business, its modern content and approaches to the organization of activities are considered. The issues of applying the principles of responsible investment and its connection with the expansion of methods for assessing the effectiveness of socially responsible activities of mining companies in Russia have been studied.
\end{abstract}

\section{Introduction}

The state of the environment requires the adoption of effective measures to reduce the manifold harm caused by humanity. The greatest damage to the environment is caused by industry (business): harmful emissions into the atmosphere, pollution of soil and water bodies, violation of the relief, land objects and water systems, the formation of huge volumes of waste and other types of damage.

Companies are now making voluntary commitments to environmental activities and include environmental issues in their strategic guidelines. These initiatives are dominated by self-regulatory practices and voluntary company initiatives. Globalization and the Internet have identified opportunities to evaluate the way any company does business, and more and more the company's attitude towards the environment is important. Transparency of corporate policy for large global players means the need to comply with requirements for corporate social responsibility, including in the environmental aspect.

However, corporate social responsibility (CSR) principles are not widely applied. Also controversial and problematic are the issues of assessing the level of CSR. Since the CSR is voluntary, stakeholders can observe some results, but often they are not verifiable. Typically, companies implement certain elements of the CSR. At the same time, it should be noted that there is a significant forecast towards the strengthening of globalization and the formation of unified approaches to the implementation of CSR principles based on existing structures. This paper will explore some areas of improving environmental approaches in the activities of companies, in particular, coal mining, in the context of CSR.

* Corresponding author: viy.77@mail.ru 


\section{Materials and Methods}

This work is based on related publications covering various aspects of CSR, environmental protection and responsible investing. We used the method of retrospective analysis, study of literary sources to study progress in approaches to the content and essence of CSR and the place in global corporate policy of environmental protection.

\section{Results and Discussion}

The feasibility of using a socially oriented business approach has been discussed for a considerable time. Back in the 19th century, with the development of the industrial revolution, philanthropy also developed - the charity of large industrialists. Some charitable projects carried out in Russia in the 19th - early 20th centuries still exist. Thus, philanthropic assistance was formed almost simultaneously with the formation of industry [1].

In the 1950s, the idea was put forward that if an organization, along with its main activity, also promotes socially significant ideas and carries out socially significant activities, then such an organization will be more effective than others [2], [3]. At the same time, society began to make a request for increasing the role of business in society, including on the most significant issues. These tendencies, supporting one another, allowed the concept of corporate social responsibility to develop to a global level as an integral part of the company's management system. The crises that have shocked society throughout the history of recent decades reinforce the importance of involving business in solving socially significant problems. Since budgetary funds are limited, the state in many countries seeks to attract business to active participation in solving many socially significant problems.

During the second half of the 20th century, approaches to the ideas and content of social responsibility were transformed and widely discussed. Based on the findings of the researchers so far, Bowman, E.H. and Haire, M. [4] presented a new approach to CSR, on the basis of which the practice of providing annual CSR reports was formed. This approach allows you to structure and formalize the economic benefits of companies from the use of CSR and makes it possible to exercise public control over the activities of companies in relation to stakeholders. As a result, the American approach to CSR was formed, in which environmental problems were among the most important parameters.

At the same time, it should be noted that environmental aspects in the composition of CSR activities during the development of these activities were not always included as elements of corporate social responsibility.

A widely used model proposed by A. B. Carroll [5] includes economic, legal, ethical and social responsibility. At the same time, the very concept of "social responsibility" is extensive and can include various components.

Currently, the most widespread concept of stakeholders (accomplices, stakeholders), laid down by R. Freeman [6], which was formed by the 1990s. The basis of this concept is the postulate that an organization functions in a certain external environment and directly or indirectly interacts with various participants in socio-economic relations. At the same time, in order to obtain the greatest effect, the organization must take into account the diverse interests of interested parties. This concept intersects with the concept of socio-ethical marketing [3], which also develops an approach that takes into account the interests of various interacting parties. At the same time, the composition of stakeholders includes internal forces - the owners of the company and employees, as well as external forces consumers, suppliers, investors, local communities, public organizations, the media, government and local authorities and others. In general, stakeholders can be grouped into three groups: 1) business; 2) society (citizens and public organizations); 3) authorities and administration. 
Each stakeholder group is specific in terms of the role it plays in the system of socioeconomic relations.

Business - forms the economic basis for the life of the territory: they make decisions about the production of a particular product, the scale of production, create a certain level of socioeconomic working conditions for workers.

Society - consumes the results of production created in the territory, acting in a certain social environment.

Authorities and authorities - provide and guarantee the rules of mutual behavior for all stakeholders at each level of government in accordance with the specifics of this level.

At the same time, CSR is designed to optimally align the often conflicting interests of stakeholders. Environmental protection is one of the important parts of the overlapping interests of stakeholders.

It should be noted that with the development of international standards (ISO), the concept of CSR becomes more global, it receives a normative basis for development. This trend has been manifested since the beginning of the XXI century, and now it is the mainstream.

ISO 26000 standard [7]. was established in 2010. It defines the main areas of the company's social activities in seven areas: organizational management, human rights, labor practices, the environment, good business practices, consumer issues, community participation and development. Thus, this standard combines issues of ensuring social stability within an organization, measures to positively influence society and public relations, and compliance with environmental protection measures.

Speaking about the system of international standards, it should be noted the ISO 14001 [8] standard, which contains requirements for the environmental management system and is currently used by companies in more than 180 countries around the world. However, ISO 14001 certification is optional. However, the presence of this certificate increases the competitive advantages of the company and positively affects its reputation, and allows for economic benefits.

A. Zelazna, M. Bojar and E. Bojar [9] showed that social responsibility associated with conducting economic activities in compliance with environmental protection requirements for local enterprises makes it possible to implement the principles of sustainable development and introduce environmental management. Enterprises responsibly analyze their impact on the use of a variety of resources in production activities and look for solutions that minimize the environmental burden on the company's activities. They motivate their employees to save paper, energy and water, and monitor their emissions to adhere to applicable emission standards and take corrective action as needed. In 2019, up to $90 \%$ of respondents indicated that they view socially responsible activities in relation to the environment as an investment, not a cost [9].

Thus, the principles of socially responsible behavior of companies are increasingly accepted by society, which gives a new development to the use of CSR.

Of course, all activities are harmful to the environment. However, there are industries that have the greatest impact on the pollution of the planet. These are the branches of the fuel and energy complex and the mining industry.

The application of in-depth, integrated and globally relevant, environmental management of mining companies is now required.In the sphere of the fuel and energy complex, the problems of greening activities and social responsibility of business are most acutely manifested. The mining industry causes significant damage to the environment, and the introduction of CSR will allow more control over the activities of mining companies.

Since Russia is a major supplier of fuel and energy resources to both foreign and domestic markets, the problems associated with strengthening corporate social responsibility, taking into account the contribution of Russian enterprises to solving environmental problems now require urgent solutions. 
Consider one of the options for controlling the environmental behavior of mining companies - responsible investing.

The mining industry and in particular the coal industry are sectors of production that require significant investment. Therefore, the analysis of trends in the field of international investment is not only theoretical, but also of significant practical importance in terms of assessing the financial stability and safety of coal enterprises. The principles of responsible investment are becoming a global financial trend in recent years. ESG criteria are the formal expression of the concept of responsible investing. For the first time, the Principales for Responsible Investment (PRI) was formulated at the initiative of the UN and with the participation of the largest institutional investors and was presented in 2006. The abbreviation ESG consists of the first letters of the words environmental, social and governance and assumes that the company seeking investment will meet these criteria. Environmental criteria define how a company acts as a guardian of nature. Social criteria examines how she manages relationships with employees, suppliers, customers, and the communities in which she works. Governance concerns the company's management, remuneration, audit, internal control and shareholder rights [10].

Until 2018-2019the applicability of ESG criteria in the field of investment was not widespread and was limited by the following factors: the lack of a clear methodology for assessing ESG factors when making an investment decision, the voluntary nature of use, the lack of comparable data, including on the risks and profitability of companies oriented towards ESG criteria and not oriented towards them. According to a report prepared in 2016 by the consulting group Steward Redqueen B.V., the growth of investors who take into account ESG criteria fell on the EU and the USA: Europe (54\%) and North America (22\%) [11].

However, in 2020-2021, the situation begins to change radically. For example, Bonita To, an institutional investor at Scotiabank in the mining industry, points to the following data: over the past two years, there has been a large increase in the number of institutional investors committed to the principles of responsible investing. About 3,000 investors are focused on taking ESG factors into account when making investment decisions, which amounts to $\$ 303$ trillion of investments under their management [12]. According to the Global Sustainable Investment Alliance, in 2020 ESG-focused ETFs recorded a net inflow of $\$ 89$ billion, almost three times more than in the previous year [12]. The significant impact of ESG indicators on the mining sector is also evidenced by the results of the Investing in the Future: ESG \& Mining forum held on September 22, 2020, dedicated to the problems of investment attractiveness of the mining sector [13].

For Russian companies, especially companies operating in the domestic market, ESG is an exclusively new direction. The independent European rating agency RAEX-Europe published the ESG rating of Russian companies in May 2021. For each criterion E, S, G, individual indicators are presented.

The five leaders included such companies as: Polymetal, LUKOIL, SIBUR Holding, Enel Russia and Russian Railways. Since we are primarily interested in the companies of the coal mining sector, it can be noted that the largest coal mining company in Russia, represented in the Kemerovo region, SUEK, is in 11th place in the rating. The summary indicators of SUEK by ESG are as follows: criterion E (environmental, ecology) - 14, S (social) - 12, G (governance) - 26. Among coal companies in Russia, SUEK is the only one included in this rating [14].

Indicated data indicating the growing interest of institutional investors in investments based on ESG criteria. 


\section{Conclusion}

Business social responsibility is now widely spread and has an impact on the results of companies. The principles of socially responsible behavior of companies are increasingly accepted by society, which gives a new development to the use of CSR.

In the mining industry, responsible investing can be a tool for doing business in a socially responsible manner. The formal expression of the concept of responsible investing is ESGcriteria, (environmental, social and governance), which assume that a company seeking investment will meet these criteria and receive certain preferences from investors.

First, the use of ESG criteria can become an element of a successful marketing policy of companies, which in the face of increasing competition can lead to a decrease in the profitability of those companies that do not take these criteria into account. Secondly, if ESG becomes an integral part of traditional financial analysis, then Russian mining companies could potentially face capital flight and become less attractive to international investors, since they do not fully use these tools.

\section{References}

1. D. Wren, The History of Management Thought (Hoboken, NJ: John Wiley Sc Sons, 2005)

2. H. R. Bowen Social Responsibilities of the Businessman (Harper \& Row: N. Y., 1953)

3. P. Kotler, Marketing Management: Analysis, Planning and Control. Englewood Cliffs (N.J.: Prentice-Hall, 1967)

4. E.H. Bowman, and M. Haire, A Strategic Posture toward Corporate Social Responsibility. California Management Review, 18, 49 (1975)

5. A.B. Carroll, A Three-Dimensional Model of Corporate Social Performanc. Acad. Manag. Rev., 497 (1979)

6. R. Freeman, J. Harrison, A. Wicks, B. Parmar, S. de Colle, Stakeholder Theory: the State of Art. Cambridge (University Press, 2010)

7. ISO 26000:2010 Guidance on social responsibility. [online] Available at: URL: https://www.iso.org/ru/standard/42546.html [Accessed 25 Apr. 2021].

8. ISO 14001:2015 - Environmental management systems - a practical guide for smes [online] Available at: URL: https://www.iso.org/ru/publication/PUB100411.html [Accessed 25 Apr. 2021]

9. A. Zelazna M. Bojar and Ewa Bojar. Sustainability, 12, 4463 (2020)

10. J. Chen. Environmental, Social, and Governance (ESG) Criteria [online] Available at: URL: // https://www.investopedia.com [Accessed 5 Mar. 2021]

11. From principles to performance: an independent evaluation of the pri's achievements and challenges at ten years (2016)

12. PRI (2021) [online] Available at: URL: https://www.unpri.org/

13. Watershed Dialogues - Investing in the Future: ESG \& Mining (2020)

14. Rating-Agentur Expert RA GmbH (RAEX-Europe) (2021) 